\title{
PBL はどのように実践されているのか
}

\author{
Study on How PBL is Practiced in Education in Japan
}

\section{大 橋 裕太郎 \\ Yutaro OHASHI}

\begin{abstract}
Currently diverse skills are needed in education in Japan, which are regarded as difficult to nurture in conventional educational methods. In response to this, two types of PBL (Problem-Based Learning and Project-Based Learning) are gaining attention. In this article author studied how PBL is practiced in education in Japan. Data are collected from article database CiNii and 2616 relevant articles were extracted. Author categorized the data into eight categories and found PBL practices were most popular in "Medicine" category in 1990s and "Engineering" in 2000s. The number of PBL practices increased generally, but "Medicine" category decreased after mid 2000s and "Engineering" after 2014. In terms of skills required in PBL practices, "Basic skills" are most required in general, while "Expertise" is most required in "Engineering" category.
\end{abstract}

Keywords : Problem Based Learning, Project Based Learning, Skills, PBL in Engineering キーワード：問題解決型学習, プロジェクト型学習, スキル, 工学系 PBL

\section{1.はじめに}

\section{1 教育現場で求められる「力」}

近年,「○○(能) 力」や「○○スキル」といった言 葉が大学案内から大学のデイプロマポリシーやカリキ ユラムといったものの中で頻繁に用いられ，会話の中 にも日常的に登場するようになった，就職活動の時期 になれば，学生たちもこうした言葉を織り交ぜながら 自己アピール文を必至に考えている姿を目にする。も はやこうした言葉なしには大学の教育が語れないので はないかと感じられるほどである。

こうした 「○○(能) 力」や「○○スキル」といっ た言葉には，この 20 年ほどの間だけでも多くのものが ある(表 1$)$ 。これ以外にも，ジェネリックスキル1 や21世紀型スキル ${ }^{2), 3)}$ といった, ある程度標準化され 国際的にも認知されているものから，より細分化され た具体的な能力を示すもの（例：プレゼンテーション (能）力, プロジェクトマネジメントスキル), 人格や 態度を表すもの（例：主体性，創造性），あるいは，対 象が広範で求める能力や人格・態度を全般的に示そう とするもの（例：生きる力）まで，様々な言葉が新し い教育のあり方を語るために用いられている。こうし た言葉は総称して〈新しい能力〉とも呼ばれている ${ }^{4)}$.

ここではそれぞれの特徵や相違点, 共通点について 検討はしないが，こうした能力概念の内容にはお抢よ そ以下のようなものが含まれている ${ }^{4)}$.

2016 年 8 月 26 日受付

※ 1 日本工業大学
- 基本的な認知能力（読み書き計算，基本的な知識 スキルなど）

- 高次の認知能力 (問題解決, 創造性, 意思決定, 学 習の仕方の学習など）

一対人関係能力（コミュニケーション,チームワーク, リーダーシップなど）

一人格特性・態度（自尊心，責任感，忍耐力など） これらに共通する特徵は，(1) 認知的な能力から人 格の深部にまでおよぶ人間の全体的な能力を含んでい ること, (2) そうした能力を教育目標や評価対象とし て位置づけていることにあるとされる ${ }^{4)}$.

\section{2 ふたつのPBL}

こうした多様で複合的な能力を養成するために注 目されているのが, 問題解決型学習 (Problem-Based Learning) とプロジェクト型学習 (Project-based learning) の，ふたつの「PBL」である. 特に大学で は様々な科目・分野でPBLに基づく研究事例・教育実 践事例が増えているとの報告がある ${ }^{5)-7)}$.

問題解決型学習 (Problem-Based Learning) は, 80 年代の初期の著作では「問題の解決や理解のための 活動プロセスを通じた学び」と簡潔に定義づけられ ている ${ }^{8)}$. 問題解決型学習は1960年代後半にカナダの McMaster 大学医学部で主要な教育・学習アプローチ として最初に導入され, それ以降, 医療系分野に特に 普及し, その後それ以外の幅広い分野において世界中 で実践されている ${ }^{9)}$.

問題解決型学習の創始者の一人であるBarrowsによ れば，問題解決型学習は特定の教授法を指すわけでは 
表 1 わが国における〈新しい能力〉概念（松下，2010 p.3）

\begin{tabular}{|c|c|c|c|}
\hline \multirow{2}{*}{\multicolumn{4}{|c|}{$\begin{array}{c}\text { 名 } \quad \text { 称 } \\
\text { 初筀.中等教育】 }\end{array}$}} \\
\hline & & & \\
\hline 生きる力 & 文部科学省 & $\begin{array}{l}\text { 中央教育審議会答申『21世紀を展望した我が国の教育の } \\
\text { 在り方について }\end{array}$ & 1996 \\
\hline リテラシー & OECD-PISA & 国立教育政策研究所編『生きるための知識と技能』 & $\begin{array}{c}2001 \\
(2004 \cdot 2007)\end{array}$ \\
\hline 人間力 & 内閣府 (経済財政諮問会議) & 『人間力戦略研究会報告書』 & 2003 \\
\hline キー・コンピテンシー & OECD-DeSeCo & ライチェン\&サルガニク『キー・コンピテンシー』 & $\begin{array}{c}2006 \\
\text { (原著2003) }\end{array}$ \\
\hline 【高等教育・職業教育】 & & & \\
\hline 就職基礎能力 & 厚生労働省 & 『若年者就職基礎能力習得のための目安策定委員会報告書』 & 2004 \\
\hline 社会人基礎力 & 経済産業省 & 『社会人基礎力に関する研究会「中間とりまとめ」報告書』 & 2006 \\
\hline $\begin{array}{l}\text { 学士力 } \\
\text { 【労働政策】 }\end{array}$ & 文部科学省 & 中央教育審議会答申『学士課程教育の構築に向けて』 & 2008 \\
\hline $\begin{array}{l}\text { エンプロイアビリティ } \\
\text { (雇用されうる能力) }\end{array}$ & $\begin{array}{l}\text { 日本経営者団体連盟 } \\
\text { (日経連) }\end{array}$ & $\begin{array}{l}\text { 『エンプロイアビリティの確立をめざして -「従業員自 } \\
\text { 律・企業支援型」の人材育成を-』 }\end{array}$ & 1999 \\
\hline
\end{tabular}

なく, 教員の能力や用いられる教授法に合わせて多様 な意味を持ちうる ${ }^{10)}$.

プロジェクト型学習 (Project-based learning) は, 意味があると生徒が考えられるような実世界の課題や 問題に対峙させ，彼ら自身がそれらにどのように取り 組むか決定し, 協調的に問題解決策を考え実行する教 授モデルである ${ }^{11)}$. 1990年代から主に工学系で発展し てきた ${ }^{12)}$. 対象が幅広く，それぞれの研究で独自の定 義がなされているため統一された見解はない ${ }^{13)}$.

ふたつの相違点については, 前者は学習プロセスが 明確に定義され活動デザインに反映されているのに対 し，後者はそれが個別の実践に委ねられているという 違いがある ${ }^{13)}$. 共通点については, 両方とも知識は学 習者が自ら構築するものであるという構成主義の考え に基づき，真正性の高い問題に少人数のグループで取 り組み，学習者自身が学びを管理・運営し，それを教 員が支えるという活動の枠組みを共有している ${ }^{13)}$.

本稿では，厳密には相違点があるものの，共通性が 高い両者を「PBL」として扱う。

\section{$1.3 \mathrm{PBL}$ 研究の特徵と課題}

PBLに関する研究の多くは, 以下の問題の 1 つ以上 を調查しようとするものとされている ${ }^{9)}$.

- PBLで学んだ学生と従来の方法で学んだ学生におけ るパフォーマンスの比較

- PBLによる学習行動や思考過程の改善

- PBLカリキュラムで学ぶ学生の満足度

ー PBLカリキュラムで学んだ卒業生における研修への 準備状態の適切さ

- PBLカリキュラムに関わる教員の満足度

多様な視点からPBLに関する研究が進められている ものの, 例えば「キー・コンピテンシー」という言葉 が揭げる価值観はあまりにも多岐にわたっており，そ うした価值にもとづく要求がどのような実践として具 体化されるのかはほとんど明らかにされていない4). そのため, 議論を「能力」から「実践」に広げ, どの
ような実践を通じて目指される価值を実現していくか に目を向ける必要があるとされている ${ }^{4)}$.

2.リサーチクエスチョン

本稿では, 議論を「能力」から「実践」に広げるべ きとの前述の指摘に基づき, PBLが日本においてどの ように実践されているかを明らかにする。リサーチク エスチョンは以下の通りである.

(1) PBLに関する実践や研究は増えているのか

(2) PBLはどのような学問分野で実践されているのか

(3) PBLではどのような力が求められているのか

(4) 工学分野においてはどのような分野でPBLが実践 されているのか

(5) 工学分野のPBLではどのような力が求められてい るのか

\section{3. 調查方法}

NII 学術情報ナビゲータ「サイニィ」(http://ci.nii. $\mathrm{ac} . \mathrm{jp} /$ ) に扔いて, 以下のキーワードで論文検索を行

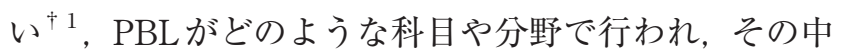
でどのような力が求められているかを調査した。 各キ ーワードと件数を表 2 に示す.

表 2 の計4,690件すべての論文名に目を通し, 重複し たデー夕と関連がないデー夕を除外した.さらに, 年が 終了していない2016年のデー夕は件数が少ないため, 今回の調査からは除外することとした。その結果残つ た2,616件を調查対象とした ${ }^{\dagger 2}$ 。この2,616件に対して,

† 1 いずれも $6 / 14$ 時点のデー夕.なおサイニイでは検索 を行うと, 論文名, 抄録, 論文誌に当該キーワードが あるかを検索する.

†2デー夕の重複を判断する上で, 論文名だけでなく雑誌 名, 出版日付 ·巻 - 号・ページ数, URL (DOI) も参 照した。データの関連性に関しては，例えば「PBL」 と表記していてもそれをProject-Based Learning, Problem-Based Learning 以外の省略記法として使用 していた場合, データを除外した. 
表 2 検索キーワードと件数

\begin{tabular}{|l|r|}
\hline \multicolumn{1}{|c|}{ キーワード } & 件数 \\
\hline PBL & 2,816 件 \\
\hline Project Based Learning & 929 件 \\
\hline Problem Based Learning & 923 件 \\
\hline プロジェクトベースドラーニング & 21 件 \\
\hline プロブレムベースドラーニング & 1 件 \\
\hline \multicolumn{1}{|c|}{ 計 } & 4,690 件 \\
\hline
\end{tabular}

論文名，キーワード，論文誌名などから判断して学問 分野または特徴的なキーワードを特定し，カテゴリー 名を作成し各論文を分類した。判断が難しい場合は抄 録や本文を読み判断した。整合性を高めるため，この 作業を 3 回繰返した.

\section{4. 結果}

\section{4. $1 \mathrm{PBL}$ 研究の件数の推移と関連学問分野}

最終的に「工学」「医療」「教育・人材育成」「PBL 一般」「その他人文社会系」「その他理系」「ICTの利活 用」「地域・産学連携」の 8 つのカテゴリーを作成し た. 複数のカテゴリーに分けられると考えられる場合 は，最も近いと考えられるカテゴリーに分類した．各 カテゴリーの発表年ごとの件数の推移をまとめた（図 1).

各カテゴリーの件数および各カテゴリーに含まれる 分野やキーワードを表 3 に示す。なお，ここでは異な るカテゴリーの中で同一の言葉が存在する場合がある (例：「工学」-「地域・産学連携」と「地域・産学連 携」). 今回の分類では, 例えば工学分野の中での地域・ 産学連携の事例であると確認できた場合は前者, 研究 領域や科目などが明らかでない，あるいは複合領域の 事例と判断した場合は後者に分類することとした.

以下，各カテゴリーの特徴を示す.

$\langle$ 工学〉

総数が最も多いのが工学分野である。工学分野での PBLの件数は2000年頃から増え始め, 2000年代中頃に, それまで最も件数が多かった医療分野を上回り，2014 年まで右肩上がりに推移した。工学分野が2010年代で

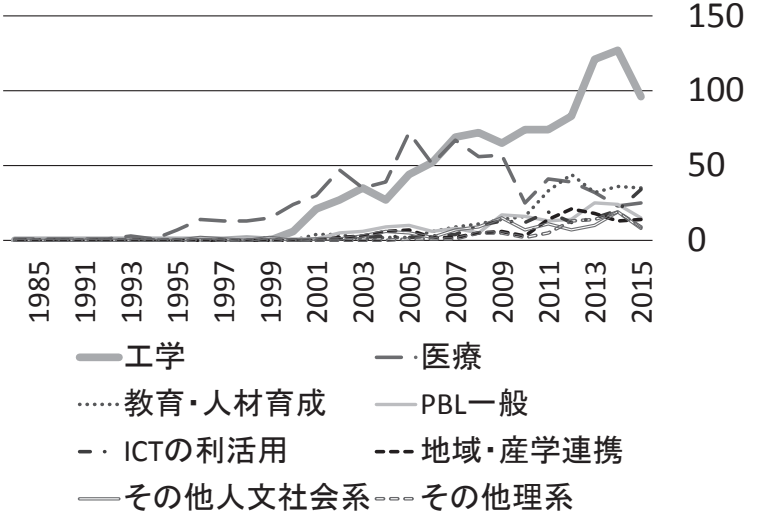

図 1 PBLを行う各カテゴリーの件数の推移
最も多くPBLを行う分野となった。なお，2014年から 2015年にかけては件数が減少している。

〈医療〉

総数が次に多いのが医療分野で，90年代に最も PBL を行っていた. 2000年代中頃まで増加傾向であったが, その後減少傾向に転じ，2015年には「教育・人材育成」 $\lceil\mathrm{ICT}$ の利活用」よりも件数が少なくなった。これに関 しては, 早くから PBLを実施した医療系大学の中には PBL を廃した大学があることや, ある特定のPBLの手 法が，学生が自己学習する時間が必要で教員への負担 が大きいといった理由から現在では実施している大学 が少ないとの報告がある ${ }^{12)}$ 。こうしたことが件数に影 響している可能性がある。

\section{〈教育・人材育成〉}

この分野は2010年以降増加傾向にある．教養教育や 必修科目,「社会人基礎力」や「就業力」といった言 葉が使われるキャリア教育などで用いられるようであ る。キャリア教育は理系文系を問わず行われている。

〈その他人文社会系・その他理系〉

人文社会系・理系問わず幅広い科目や学問分野で PBLが用いられている。 人文社会系は2010年代に入っ て，件数が増えている.

表 3 カテゴリーごとの件数と分野・キーワード

\begin{tabular}{|c|c|}
\hline カテゴリー名 & 分野・キーワード \\
\hline 工学（994件） & $\begin{array}{l}\text { 情報, 電気電子・機械・ものづくり, 工学一般, } \\
\text { 設計・デザイン, 非技術系スキル, 地域・産学連 } \\
\text { 携, その他工学 }\end{array}$ \\
\hline 医療（734件） & 医学, 看護, 薬学, 歯学, 福祉, 保健, 理学療法 \\
\hline $\begin{array}{c}\text { 教育 } \cdot \text { 人材育成 } \\
(252 \text { 件 })\end{array}$ & 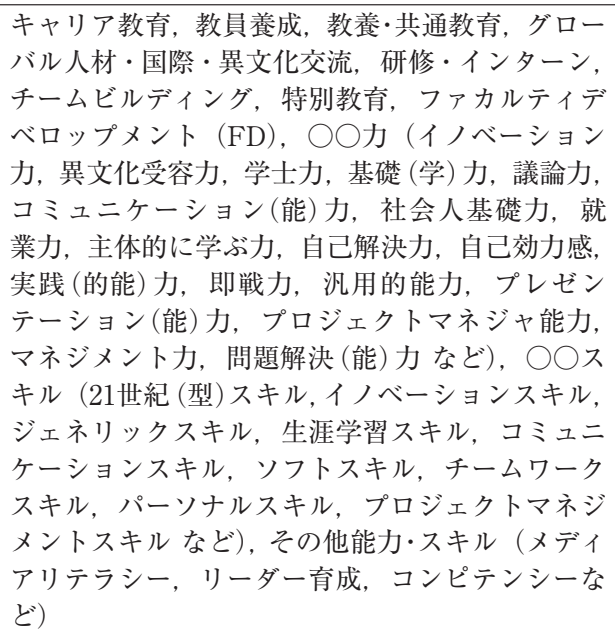 \\
\hline & $\begin{array}{l}\text { PBLの運営·評価方法, PBLを取り入れたカリキュ } \\
\text { ラム, または分野・キーワード特定不可能 }\end{array}$ \\
\hline $\begin{array}{l}\text { その他人文 } \\
\text { 社会系 } \\
(150 \text { 件 })\end{array}$ & $\begin{array}{l}\text { 映像, 開発教育, 家庭科, 環境教育, 観光学, 学 } \\
\text { 校行事, 金融, 経営学, 経済学, 芸術, 語学, 商 } \\
\text { 学, 心理学, 生活科, 総合学習, 体育, デザイン, } \\
\text { 図書館・ラーニングコモンズ, 美術, 文学, 倫理 } \\
\text { 教育, 歴史学 }\end{array}$ \\
\hline $\begin{array}{r}\text { その } \\
(1\end{array}$ & $\begin{array}{l}\text { 栄養学, 科学, 化学, 建築, 土木, 数学, 地理 · } \\
\text { 地学, 農林水産学, 理学 }\end{array}$ \\
\hline $\begin{array}{r}\text { ICTの } \\
(11\end{array}$ & IC \\
\hline $\begin{array}{c}\text { 地域・産学連携 } \\
\text { (75件) }\end{array}$ & $\begin{array}{l}\text { 地方自治体や地域の学校との連携, 地元企業や商 } \\
\text { 店などとの連携・共同研究 - 開発 }\end{array}$ \\
\hline
\end{tabular}


〈ICT の利活用〉

情報・工学分野に関わらずICTを利用したり，PBL を支える仕組み（システム・ッール・教材など）が開 発されたり比較検討されたりしている.

〈地域・産学連携〉

分野を問わず，地方自治体，地域の学校や企業など と連携する例が増えている．大学での教育・学習が学 校の外へと飛び出している様子が伺える.

\section{$4.2 \mathrm{PBL}$ で求められる「力」}

次に, PBLの実践ではどのような「力」が求められ ているかを調べた。 上記の 2,616 件の中で，「○○力」 $\lceil ○ ○$ 性」「○○人材」「○○スキル」「○○思考・○○ シンキング」「コンピテンシー」「リテラシー」のいず れかのキーワードが論文名に記載されているものを抽 出したところ, 295件が該当した ${ }^{\dagger 3}$. その中からキーワ ードのみを抜き出し，同一と思われるキーワードを同 じものとして語句を整理した（例：「問題解決力」「問 題解決能力」「問題解決スキル」など). キーワードを 類似性から分類し，「基礎力」「専門性·職業」「コミュ

表 4 PBL実践で求められている「力」

\begin{tabular}{|c|c|}
\hline カテゴリー名 & キーワード \\
\hline & 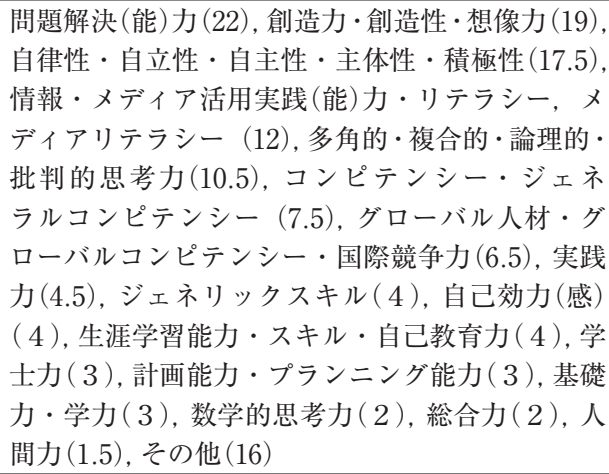 \\
\hline $\begin{array}{r}\text { 専門性 · } \\
\quad(126.5\end{array}$ & 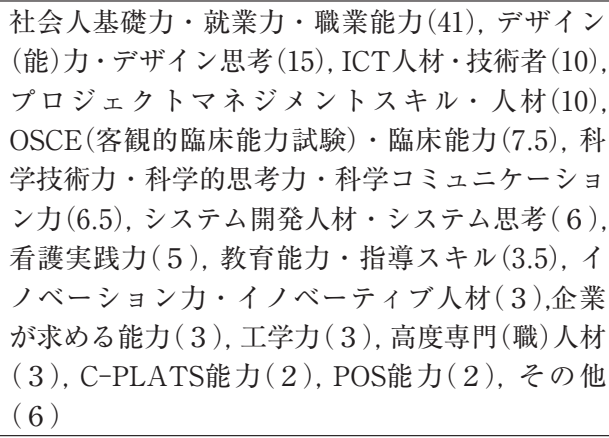 \\
\hline $\begin{array}{c}\text { コミュニケー } \\
\text { ション } \\
(26.5 \text { 件 })\end{array}$ & $\begin{array}{l}\text { コミュニケーション能力・スキル・対話力・議論 } \\
\text { カ・討論力 }(17) \text {, チーム活動能力・チームワーク } \\
\text { スキル }(3) \text {, 英語力・英語コミュニケーションカ } \\
(2), \text { リーダー型人材・リーダーシップ }(2) \text {, パー } \\
\text { ソナルスキル }(1.5), \text { 協調性 }(1)\end{array}$ \\
\hline
\end{tabular}

†3ひとつの論文名にふたつのキーワードがあった場合, それぞれを 0.5 としてカウントした．また，例えば「能 力」という言葉が単独で使われ, 具体的な能力が推定 できない場合は除外した，当然ながら，「電力」や「風 力」, あるいは「協力」といった個人の能力と関倸ない ものは除外した.
ニケーション」の 3 つのカゴリーを作成した. PBL 実践全体では「基礎力」に関するものが最も多く, 次 いで「専門性・職業」,「コミュニケーション」の順と なった（表 4).

\section{3 工学分野のPBL}

続いて, 工学分野の994件の論文に対して, 論文名, キーワード, 論文誌名などから判断して, 学問分野の サブカテゴリーを作成し，論文を分類した．サブカテ ゴリーは最終的に「情報」「電気電子・機械・ものづ くり」「工学一般」「設計・デザイン」「非技術系スキ ル」「地域・産学連携」「その他工学」の 7 種類となっ た（図 2 , 表 5 ).

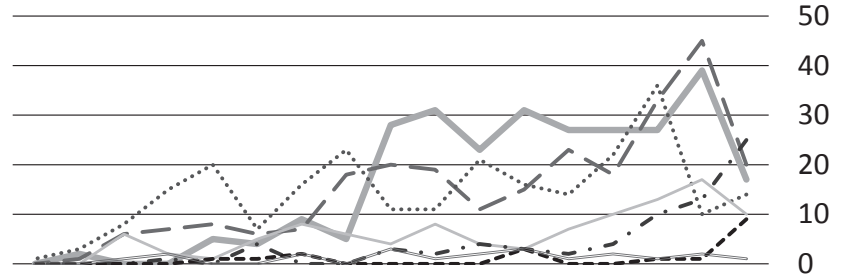

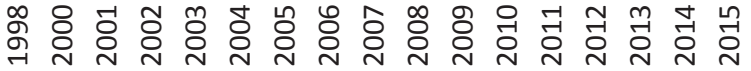 一情報 \\ ……学一般 \\ -・非技術系スキル 一その他工学 \\ 一電気電子·機械·ものづくり \\ 一設計・デザイン --・地域·産学連携}

図 2 工学分野各カテゴリーのPBLの件数の推移

表 5 工学分野のサブカテゴリーと分野・キーワード

\begin{tabular}{|c|c|}
\hline $\begin{array}{c}\text { サブ } \\
\text { カテゴリー名 }\end{array}$ & 分野・キーワード \\
\hline $\begin{array}{l}\text { 情報 } \\
(275 \text { 件) }\end{array}$ & $\begin{array}{l}\text { 情報科学・工学, プログラミング教育, 情報通信· } \\
\text { ネットワーク, フィジカルコンピューティング, } \\
\text { ソフトウェア・システム開発・工学, アプリケー } \\
\text { ション開発, IT技術者育成, 情報モラル・倫理 } \\
\text { 教育, 情報セキュリティ, 情報アーキテクチャ, } \\
\text { 情報デザイン, データマイニング, アジャイル, } \\
\text { ウェブ, クラウド, ゲーム, AI }\end{array}$ \\
\hline $\begin{array}{c}\text { 電気電子・機械・ } \\
\text { ものづくり } \\
(257 \text { 件 })\end{array}$ & $\begin{array}{l}\text { 電気·電子工学, 機械工学, 工作·工作機械, フォー } \\
\text { ミュラカー, ソーラーカー, レーシングカー, ラ } \\
\text { イントレース, ロボット, 飛行機, ロボットコン } \\
\text { テスト, ロケット, 回路, マイコン, 玩具, エネ } \\
\text { ルギー, 測定機器, ものづくり }\end{array}$ \\
\hline $\begin{array}{l}\text { 工学一般 } \\
\text { (248件) }\end{array}$ & 工学一般, または分野・キーワード特定不可能 \\
\hline $\begin{array}{c}\text { 設計・デザイン } \\
(104 \text { 件 })\end{array}$ & $\begin{array}{l}\text { シミュレーション, モデリング, CAD, 設計, } \\
\text { デザイン, エンジニアリングデザイン, デザイン } \\
\text { 思考, 製図, }\end{array}$ \\
\hline $\begin{array}{c}\text { 非技術系スキル } \\
\text { (71件) }\end{array}$ & $\begin{array}{l}\text { アントレプレナーシップ, プロジェクトマネジメ } \\
\text { ント, マネジメントカ, グローバルスキル, キャ } \\
\text { リア教育, プレゼンテーションカ, イノベーショ } \\
\text { ンスキル, リーダーシップ, 倫理教育, ディベー } \\
\text { ト・議論力, サービス設計, 技術経営 }\end{array}$ \\
\hline $\begin{array}{c}\text { 地域・産学連携 } \\
\text { (18件) }\end{array}$ & の自治体や令 \\
\hline $\begin{array}{c}\text { その他工学 } \\
\text { (21件) }\end{array}$ & $\begin{array}{l}\text { 宇宙工学, 材料 } \\
\text { 人間工学 }\end{array}$ \\
\hline
\end{tabular}


表 6 工学分野の PBLで求められている「力」

\begin{tabular}{|c|c|}
\hline 名 & キーワード \\
\hline $\begin{array}{c}\text { 職業 · 専門性 } \\
(57)\end{array}$ & $\begin{array}{l}\text { デザイン思考・デザイン能力 (13), ICT技術者・ } \\
\text { 人材 }(11) \text {, 社会人基礎力・就業力 }(11) \text {, システム思 } \\
\text { 考・システム開発人材 }(5) \text {, 技術力・科学技術力 } \\
(4) \text {, 工学力 }(3) \text {, プロジェクト人材・ プロジェク } \\
\text { トマネジャ能力・マネジメント力 }(3) \text {, イノベー } \\
\text { ションカ・スキル }(2) \text {, その他 }(5)\end{array}$ \\
\hline $\begin{array}{l}\text { 基礎力 } \\
(45.5)\end{array}$ & 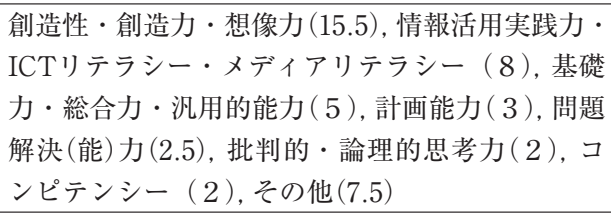 \\
\hline $\begin{array}{l}コ ミ ュ ニ ケ ー \\
\text { ション }(6.5)\end{array}$ & $\begin{array}{l}\text { 討論スキル・対話力·議論力 (3), チーム活動能力· } \\
\text { チームワークスキル }(2) \text {, リーダー型人材 }(1) \text {, 協 } \\
\text { 調性 }(0.5)\end{array}$ \\
\hline
\end{tabular}

以下，各サブカテゴリーの特徵を示す

〈情報，電気電子・機械・ものづくり，工学一般〉

この 3 つは学分野で件数が上位のサブカテゴリー であり，2000年頃から増加し始めた．しかし， 3 分野 とも2014年または2015年に件数が減少しており，工学 分野全体の最近の件数の落ち込みに影響している.

〈設計・デザイン〉

工学分野全般でコンピュータを使うことが一般的に なっているためか「設計・デザイン」のサブカテゴリ 一は上位のサブカテゴリーほどではないものの全体と して増加傾向にある. 最も件数が多かったのが2014年 で2015年には件数が減少している.

〈非技術系スキル〉

ここ 5 年で最も件数が伸びているのが「非技術系ス キル」である．2011年から増加し，2015年は「情報」 を抜き最も件数が多い分野となった。

\section{4 工学分野のPBLで求められる「力」}

工学分野の994件の中から先ほどと同様の手続きで, 個人の能力に関するキーワードを抽出したところ, 109 件の論文が該当した，先ほどと同じ「基礎力」「専門 性·職業」「コミュニケーション」の3つのカテゴリー に分類したところ，「職業・尃門性」の件数が最も多か った（表 6 )。これは，「基礎力」が最も多かった全分 野のPBL実践とは異なる結果となった.

\section{5. 考察}

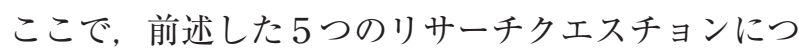
いて考察する.

(1) および (2) PBL研究の件数の推移と学問分野

PBLが実践されている分野として「工学」「医療」「教 育・人材育成」「PBL一般」「その他人文社会系」「そ の他理系」「ICT の利活用」「地域・産学連携」の 8 つ のカテゴリーを作成した，文系理系を問わず幅広い分 野でPBLが実践されていることが分かった.

PBLの件数は全体として増加傾向にあるものの, 減
少傾向にある分野もあることが分かった.PBLをいち 早く取り入れていた医療分野では2000年代から件数が 減少している. 教員負担が大きいことなどから PBLを 廃する大学が出ているとの報告があり，こうしたこと が起因している可能性がある. あるいは, PBLが一般 化した結果, PBLに関する研究が落ち着いたことや, PBLとは別の名称が使われるようになった可能性も考 えられる。

工学分野では2014年を頂点として2015年に件数が大 きく減少した. 工学分野の件数の減少は 1 年間だけで あるため,この傾向が今後も続くのかは未知数である. 両分野とも, 減少の理由は今回の調査からだけでは判 断できないため, 引き続き調査が必要である.

一方，「教育・人材育成」「ICT の利活用」「地域・産 学連携」は2010年代に入って増加傾向にある.

(3) PBLで求められる「力」

能力やスキルに関するキーワードを集計し，「基礎 力」「専門性・職業」「コミュニケーション」の 3 つの カテゴリーを作成した。全分野の PBL 実践では「基礎 力」に関するものが最も多かった。

(4) 工学分野の PBL

工学分野でPBLが行われている分野として，「情報」 「電気電子・機械・ものづくり」「工学一般」「設計・デ ザイン」「非技術系スキル」「地域・産学連携」「その 他工学」の 7 種類のサブカテゴリーを作成した. 工学 分野全体ではPBLの実践は増加傾向にあるが,「情報」 「電気電子・機械・ものづくり」「工学一般」はここ数 年件数が減少しており，このことも影響し2015年の工 学分野全体の件数は減少した.

（5）工学分野の PBLで求められる「力」

「基礎力」が最も多かった全分野のPBL実践とは異 なり, 工学分野では「職業・専門性」に焦点が当てら れていることが分かった．工学分野ではハード・ソフ トを含めた「ものづくり」がひとつの基本として考え られているものの, 最近ではマネジメントやチームの 中での他者との協力といったスキルが「情報」や「電 気電子・機械・ものづくり」よりも多くなっていた. この傾向が今後も続くのかは未知数である.

\section{6. まとめ}

PBLが教育の中でどのように実践されているか調査 し, 実践分野として8つのカテゴリーを作成した. PBL に関する研究・報告件数は全体的に増加傾向にあるも のの, 減少している分野もあることが分かった. PBL が教育現場に根付くには, 負担の少ない効率的な評価・ 運営手法が不可欠であると考えられる. PBLに求めら れる能力としては, 全体では「基礎力」に焦点が当て られている一方で, 工学分野では「職業・専門性」に 焦点が当てられていることが分かった. 


\section{参 考 文 献}

1 ) Kearns, P.:Generic Skills for the New Economy: Review of Research. National Centre for Vocational Education Research, 2001

2 ) Ananiadou, K. and Claro, M. : 21st Century Skills and Competencies for New Millennium Leaners in OECD Countries. EDU Working paper no. 41, OECD, 2009. Webページ, http://www.oecd.org/ officialdocuments/publicdisplaydocumentpdf/?c ote $=\mathrm{EDU} / \mathrm{WKP}(2009) 20 \&$ doclanguage $=\mathrm{en}$, 参照 日：2016-8-25

3) P. グリフィン, B. マクゴー, E. ケア：21世紀型 スキルー学びと評価の新たなかたち, 北大路書房, 2014

4 ）松下佳代 編著：〈新しい能力〉は教育を変えるか: 学力・リテラシー・コンピテンシー, ミネルヴァ 書房, 2010

5 ）日本PBL研究所:PBLとは?,Webページ, http:// www.pbl-japan.com/pbl.html, 参照日 : 2016-8-25

6 ）上田勇仁, 合田美子, 根本淳子, 鈴木克明：問題 解決型学習デザインの実践状況と特徵 - Project Based Learning とProblem Based Learningを中 心に, 教育システム情報学会第36回全国大会論文 集, pp.346-347, 2011

7 ）森本千佳子：PBLを活用したコミュニケーション スキルの向上に関する研究, プロジェクトマネジ メント学会2014年度春季研究発表大会予稿集, pp. $414-417,2014$

8 ) Howard S., Barrows, M.D., Robyn M., and Tamblyn, B.Sc.N. : Problem-Based Learning :
An Approach to Medical Education, Springer Publishing Company, 1980

9 ) Schwartz, P., Mennin, S., Webb, G. : PBL世界の大 学での小グループ問題基盤型カリキュラム導入の 経験に学ぶ, 篠原出版新社, 2007

10) Barrows, H.S. : A taxonomy of problem-based learning methods, Medical Education 1986, 20, $481-486,1986$

11) Bender, W.N. : Project-Based Learning: Differentiating Instruction for the 21st Century, Corwin, 2012

12）小野和宏, 松下佳代: 教室と現場をつなぐPBL - 学 習としての評価を中心に一, 松下佳代(編著)『デ イープ・アクティブラーニング 大学授業を深化 させるために』, 勁草書房, 2015

13）湯浅且敏, 大島 純, 大島律子：PBLデザインの 特徵とその効果の検討, 静岡大学情報学研究, 16 , pp.15-22, 2011

著 者 紹 介

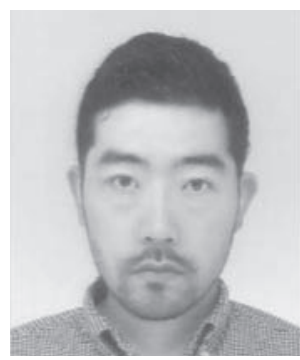

\section{大橋 裕太郎}

日本工業大学

情報・メディア教育のカリキュラムや，情 報・メディア教育を支援するゲームに関す る研究を扤こなっている 